\title{
OPERATOR INEQUALITIES VIA GEOMETRIC CONVEXITY
}

\author{
Mohammad Sababheh, Hamid Reza Moradi and Shigeru Furuichi
}

Abstract. The main goal of this paper is to present new generalizations of some known inequalities for the numerical radius and unitarily invariant norms of Hilbert space operators. These extensions result from a special treatment of both convex and geometrically convex functions. In the end, we present several scalar inequalities for geometrically convex functions similar to those inequalities known for convex functions.

Mathematics subject classification (2010): 47A30, 47A12, 47A63, 47B15, 15A60. radius.

Keywords and phrases: Geometrically convex function, operator norm, norm inequality, numerical

\section{REFERENCES}

[1] T. Ando, Concavity of certain maps on positive definite matrices and applications to Hadamard products, Linear Algebra Appl., 26 (1979), 203-241.

[2] R. BhatiA AND P. GROVER, Norm inequalities related to the matrix geometric mean, Linear Algebra Appl., 437 (2012), 726-733.

[3] S. S. Dragomir, A new refinement of Jensen's inequality in linear spaces with applications, Math. Comput. Modelling., 52 (2010), 1497-1505.

[4] S. S. DRAGOMIR, Power inequalities for the numerical radius of a product of two operators in Hilbert spaces, Sarajevo J Math., 5(18) (2009), 269-278.

[5] M. El-Haddad AND F. KitTANEH, Numerical radius inequalities for Hilbert space operators. II, Studia Math., 182(2) (2007), 133-140.

[6] T. Furuta, J. Mićić Hot, J. PeČARIĆ AND Y. SeO, Mond-Pečarić method in operator inequalities, Element, Zagreb, 2005.

[7] I. H. GÜMÜŞ, H. R. Moradi AND M. SABABHeH, More accurate operator means inequalities, J. Math. Anal. Appl., 465 (2018), 267-280.

[8] F. HIAI AND X. ZHAN, Inequalities involving unitarily invariant norms and operator monotone functions, Linear Algebra Appl., 341 (2002), 151-169.

[9] F. KitTANEH, A numerical radius inequality and an estimate for the numerical radius of the Frobenius companion matrix, Studia Math., 158(1) (2003), 11-17.

[10] F. Kittaneh, Norm inequalities for fractional powers of positive operators, Lett. Math. Phys., 27 (1993), 279-285.

[11] F. KitTAnEH, Notes on some inequalities for Hilbert space operators, Publ. Res. Inst. Math. Sci., 24 (1988), 283-293.

[12] J. Mićić, Y. Seo, S. E. TAKAhasi And M. Tominaga, Inequalities of Furuta and Mond-Pečarić, Math. Ineq. Appl., 2(1) (1999), 83-111.

[13] F. Mitroi, About the precision in Jensen-Steffensen inequality, An. Univ. Craiova Ser. Mat. Inform., 37(4) (2010), 73-84.

[14] C. P. Niculescu, Convexity according to the geometric mean, Math. Inequal. Appl., 3(2) (2000), $155-167$.

[15] M. S ABABHEH, Convexity and matrix means, Linear Algebra Appl., 506 (2016), 588-602.

[16] M. SABABHEH, Interpolated inequalities for unitarily invariant norms, Linear Algebra Appl., 475 (2015), 240-250. 
[17] M. S AвАвнEH, Log and harmonically log-convex functions related to matrix norms, Oper. Matrices., 10(2) (2016), 453-465.

[18] M. SABABHeH, Means refinements via convexity, Mediterr. J. Math., 14(3) (2017), 125.

[19] M. SAвавнеH, Graph indices via the AM-GM inequality, Discrete Appl. Math., 230(4) (2017), 100111.

[20] M. S ABABHEH, Extrapolation of convex functions, Filomat., 32 (1) (2018), 127-139.

[21] K. Shebrawi And H. Albadawi, Numerical radius and operator norm inequalities, J. Inequal. Appl., 2009 (2009), 1-11.

[22] P. VASIĆ AND J. PEČARIĆ, On the Jensen inequality, Univ. Beograd. Publ. Elektrotehn Fak. Ser. Mat. Fis., 634/677 (1979), 50-54.

[23] L. ZoU, An arithmetic-geometric mean inequality for singular values and its applications, Linear Algebra Appl., 528 (2017), 25-32. 